\title{
訃報
}

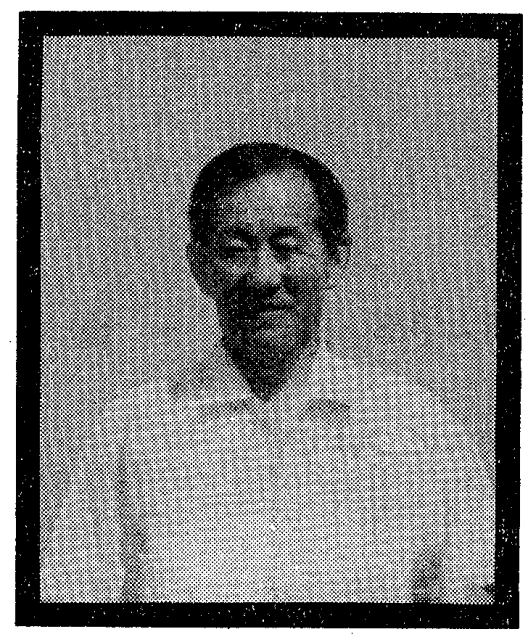

本籍地 東京都太田区北馬込 2 丁目 52 番 6 号

現住所 東京都太田区北馬込 2 丁目72番

本会監事初田義一

大正 8 年 5 月 13 日生

御逝去 昭和 51 年 2 月 21 日

\section{初田義一氏略 歴}

昭和 9 年 4 月 東京瓦斯電気工業株式会社入社

昭和15年 1 月 横須賀海兵団入団 横須賀海軍病院 - 病 院船水川丸勤務

昭和 20 年 11 月 国立久里浜病院勤務

昭和 21 年 7 月 三共株式会社品川工場勤務現在に至る

昭和 21 年 日本放射線技術学会入会（会員番号1994号）
昭和 25 年 $\sim 27$ 年
日本放射線技術学会東京支部幹事
昭和29年 30年 同 上
昭和 32 年 37 年 同 上
昭和 41 年 $\sim 44$ 年 同上
昭和 45 年
日本放射線技術学会東京支部監事
昭和49年 $\sim 50$ 年
日本放射線技術学会監事

串

ととに謹んで本会監事故初田義一先生のみたまに対し 衰悼の辞を捧げます：先生は昭和 21 年当学会に入会以来 永年に亘り支部役員を歴任せられ昭和 49 年 4 月, 東京総 会において東京支部推鹰のもとに昭和 49 年度当学会監事 に就任を賜わりました，その後更に昭和50年度に再任， 常に温厚篤実なる人と為りを以って会務運営にご尽力を 傾注して下さいました. 特に法人申請段階の昭和 49 年度 は発起人の一員として種々ご指導ご援助を賜わる外にそ の豊かな財務経験より常に適切な御指導を仰ぐことがで きました。

今回の余りにも突然ので急逝には言葉の申し上げよう あございません：で怨報を承りました当日はあたかも第 3 回理事会当日の早朝でありました. 定刻集会した役員

\section{辞}

一同に本当に青天の霹雲の如く先生のご悲報が伝えられ 一同只々吅然とするばかりでした．ご家族の皆様も同様 であった所と相察し心よりで用慰申し上げる次第であり ます. 法人化達成後実務初年度として更に先生ので指導, ご援助を期待しているとき惜しみても余りあるを痛感い たします。

初田先生どうぞ幽明簧境の地より学術法人としての当 学会の今後の発展を例の温顔を以って見つめお守り下さ (2).

心よりご冥福をお新りし用辞といたします。 昭和51年 2 月 22 日

社団法人 日本放射線技術学会

$$
\text { 会長上田 }
$$

